\title{
JUKMAS
}

Jurnal Untuk Masyarakat Sehat (JUKMAS)

e-ISSN : 2715-7687

Vol. 4, No. 1 April 2020

\section{Angka Kejadian Sunting di Wilayah Kerja Unit Pelaksana Teknis (UPT) Puskesmas Sukamulya Tahun 2019}

\author{
Dewi Yuliana Lestari, Dono Koesoema Atmodjo, Hotman Simanjuntak, Iyan Apriyanto, \\ Mulyadi, Muslim, Riyo Priyono, Yeny Sulistyowati \\ Universitas Respati Indonesia \\ Email: yeny.sulistyowati@urindo.ac.id
}

\begin{abstract}
ABSTRAK
Data Riset Kesehatan Dasar (Riskesdas) Prevalensi balita pendek mengalami peningkatan dari tahun 2016 yaitu 27,5\% menjadi 29,6\% pada tahun 2017. Oleh karena itu, kasus stunting pada anak dapat dijadikan prediktor rendahnya kualitas sumber daya manusia suatu negara. Stunting pada anak merupakan manifestasi jangka panjang dari faktor konsumsi diet berkualitas rendah, morbiditas, penyakit infeksi berulang, dan faktor lingkungan. Data di UPT Puskesmas Sukamulya tahun 2019 ditemukan 5 balita dengan gizi buruk dan berjenis kelamin perempuan. Balita di bawah garis merah ada 77, terdiri dari 41 laki-laki dan 36 perempuan. Berarti ada $1,6 \%$ balita yang di bawah garis merah, atau dengan status gizi kurang. Penelitian ini diharapkan dapat dijadikan informasi terbaru mengenai Angka Kejadian Sunting di Wilayah Kerja UPT Puskesmas Sukamulya Tahun 2019, yang bermanfaat bagi dunia keilmuan kesehatan yang dapat dikembangkan untuk bahan penulisan selanjutnya. Populasi pada penelitian ini adalah seluruh data kunjungan bayi yang bertempat tinggal di Wilayah Kerja UPT Puskesmas Sukamulya Tahun 2019. Sampel yang di gunakan dalam penulisan ini adalah purposive sampel yaitu anak-anak yang memiliki kriteria Stunting di Wilayah Kerja UPT Puskesmas Sukamulya Tahun 2019. Pengambilan data dilaksanakan pada Bulan Januari 2020. Hasil penelitian ini ditemukan bahwa pada anak usia 0-59 bulan yang mengalami stunting di Wilayah Kerja UPT Puskesmas Sukamulya pada Tahun 2019, berjumlah 123 anak (8.5\%) dari 1.444 kunjungan bayi yang dilakukan oleh tenaga kesehatan Puskesmas Sukamulya pada Tahun 2019. Desa Kaliasin merupakan desa penyumbang kasus stunting tertinggi pertama pada tahun 2019 di wilayah kerja Puskesmas Sukamulya yaitu dengan jumlah kasus 64 anak dari 123 kasus stunting.
\end{abstract}

Kata kunci: stunting, kunjungan tenaga kesehatan, desa

\section{ABSTRACT}

Basic Health Research Data (Riskesdas) The prevalence of short toddlers has increased from 2016 which is $27.5 \%$ to $29.6 \%$ in 2017 . Therefore, the case of stunting in children can be a predictor of the low quality of a country's human resources. Stunting in children is a long-term manifestation of low-quality diet consumption factors, morbidity, recurrent infectious diseases, and environmental factors. Data in UPT Sukamulya Health Center in 2019 found 5 toddlers with malnutrition and female sex. Under the red line there are 77 toddlers, consisting of 41 boys and 36 girls. Means that there are $1.6 \%$ of children under five who are under the red line, or with nutritional status. This research is expected to be used as the latest information on the incidence rate in the work area of Sukamulya 
Public Health Center in 2019, which is beneficial to the world of health science that can be developed for further writing material. The population in this study was all data of infants' visits residing in the Sukamulya Puskesmas UPT Working Area in 2019. The sample used in this study was purposive samples, namely children who had the Stunting criteria in the UPT Puskesmas Sukamulya Working Area in 2019. Data collection conducted in January 2020. The results of this study found that in children aged 0-59 months who experienced stunting in the Sukamulya Puskesmas UPT Working Area in 2019, a total of 123 children (8.5\%) out of 1,444 infant visits were made by health staff at the Sukamulya Puskesmas in Year 2019. Kaliasin Village is the first highest contributor of stunting cases in 2019 in the working area of Sukamulya Health Center, with 64 cases of 123 stunting cases.

Keywords: stunting, visits of health workers, villages

\section{PENDAHULUAN}

Setiap Negara di dunia mengalami permasalahan gizi, yaitu single burden, double burden, dan triple burden. Pada tahun 2017 $22,2 \%$ atau sekitar 150,8 juta balita di dunia mengalami stunting, 7,5\% atau sekitar 50.5 juta balita didunia mengalami wasting, $5,6 \%$ atau sekitar 38,3 juta balita mengalami overweight. ${ }^{(1)}$

Kejadian balita pendek atau biasa disebut dengan stunting merupakan salah satu masalah gizi yang dialami oleh balita di dunia saat ini. Namun angka ini sudah mengalami penurunan jika dibandingkan dengan angka stunting pada tahun 2000 yaitu 32,6\%.Pada tahun 2017, lebih dari setengah balita stunting di dunia berasal dari Asia (55\%) sedangkan lebih dari sepertiganya (39\%) tinggal di Afrika. Dari 83,6 juta balita stunting di Asia, proporsi terbanyak berasal dari Asia
Selatan $(58,7 \%)$ dan proporsi paling sedikit di Asia Tengah (0,9\%). ${ }^{(2)}$

Data di UPT Puskesmas Sukamulya tahun 2019 ditemukan 5 balita dengan gizi buruk dan berjenis kelamin perempuan. Semua penderita mendapatkan perawatan gizi dari petugas di UPT Puskesmas Sukamulya, dengan diantaranya mendapatkan makanan tambahan berupa susu dan biskuit. Disamping itu pemantauan status gizi terhadap balita gizi buruk juga dilaksanakan oleh petugas gizi secara rutin. Balita di bawah garis merah ada 77 , terdiri dari 41 laki-laki dan 36 perempuan. Berarti ada $1,6 \%$ balita yang di bawah garis merah, atau dengan status gizi kurang. ${ }^{(3,4)}$

Data Riset Kesehatan Dasar (Riskesdas) Prevalensi balita pendek mengalami peningkatan dari tahun 2016 yaitu $27,5 \%$ menjadi $29,6 \%$ pada tahun 2017. Oleh karena itu, kasus stunting pada anak dapat 


\begin{abstract}
dijadikan prediktor rendahnya kualitas sumber daya manusia suatu negara. Stunting pada anak merupakan manifestasi jangka panjang dari faktor konsumsi diet berkualitas rendah, morbiditas, penyakit infeksi berulang, dan faktor lingkungan. Berat Badan Lahir (BBL) anak dan pendapatan per kapita keluarga juga merupakan faktorfaktor yang berhubungan dengan kejadian stunting pada balita. ${ }^{(5,6)}$

Berdasarkan uraian latar belakang di atas, penelitian tentang "Angka Kejadian Sunting di Wilayah Kerja UPT Puskesmas Sukamulya Tahun 2019". Penelitian ini diharapkan dapat dijadikan informasi terbaru mengenai Angka Kejadian Sunting di Wilayah Kerja UPT Puskesmas Sukamulya Tahun 2019, yang bermanfaat bagi dunia keilmuan kesehatan yang dapat dikembangkan untuk bahan penulisan selanjutnya.
\end{abstract}

\section{METODE PENELITIAN}

Pendekatan waktu pengumpulan data retrospektif, dimana dalam mengukur variabel dilakukan dalam dengan menggunakan data terdahulu. Keduanya diukur secara bersamaan dalam waktu yang berbeda. Populasi pada penelitian ini adalah seluruh data kunjungan bayi yang bertempat tinggal di Wilayah Kerja UPT Puskesmas Sukamulya Tahun 2019. Sampel yang di gunakan dalam penulisan ini adalah purposive sampel yaitu anakanak yang memiliki kriteria Stunting di Wilayah Kerja UPT Puskesmas Sukamulya Tahun 2019. Pengambilan data dilaksanakan pada Bulan Januari 2020.

Dalam penulisan, data yang diperoleh masih mentah, belum memberikan informasi apa-apa dan belum siap untuk disajikan. Karena hal tersebut, maka pengolahan data penting dilakukan untuk memperoleh penyajian data sebagai hasil yang berarti dan kesimpulan yang baik. analisis statik yang digunakan dalam penulisan ini adalah analisis univariat (deskriptif) yaitu bertujuan untuk menjelaskan atau mendeskripsikan karaketeristik setiap variabel penulisan ${ }^{(7)}$.

\section{HASIL}

Berdasarkan hasil analisa data Laporan Rekapitulasi Masalah Gizi hasil kunjungan bayi oleh tenaga kesehatan Puskesmas Sukamulya, terdapat temuan pada anak usia 059 bulan yang mengalami stunting di Wilayah Kerja UPT Puskesmas 
Sukamulya pada Tahun 2019, hal ini

dapat dilihat pada Tabel 1.

Tabel 1

Jumlah anak usia 0-59 bulan yang mengalami stunting di Wilayah Kerja UPT Puskesmas Sukamulya pada Tahun 2019

\begin{tabular}{cccc}
\hline \multirow{2}{*}{ Hasil } & \multicolumn{2}{c}{ Anak usia 0-59 bulan } & Jumlah \\
\cline { 2 - 3 } & Stunting & Non Stunting & \\
Frekuensi & 123 & 1321 & 1.444 \\
\hline Presentase & $8.5 \%$ & $91.5 \%$ & $100 \%$ \\
\hline
\end{tabular}

Berdasarkan Tabel 1, dari data hasil kunjungan bayi terdapat temuan pada anak usia 0-59 bulan yang mengalami stunting di Wilayah Kerja UPT Puskesmas Sukamulya pada Tahun 2019, berjumlah 123 anak (8.5\%) dari 1.444 kunjungan bayi yang dilakukan oleh tenaga

\begin{abstract}
kesehatan Puskesmas Sukamulya pada Tahun 2019.

Distribusi frekuensi berdasarkan Desa temuan stunting pada anak usia 0-59 bulan di Wilayah Kerja UPT Puskesmas Sukamulya pada Tahun 2019, dapat dilihat pada Tabel 2.
\end{abstract}

Tabel 2

Jumlah Anak Usia 0-59 Bulan Yang Mengalami Stunting Berdasarkan Desa di Wilayah Kerja UPT Puskesmas Sukamulya pada Tahun 2019

\begin{tabular}{|c|c|c|c|c|c|c|}
\hline \multirow{2}{*}{ Desa } & \multicolumn{4}{|c|}{ Anak usia 0-59 bulan } & \multirow{2}{*}{$\begin{array}{l}\text { Frekuensi } \\
\text { Kunjungan } \\
\text { Bayi }\end{array}$} & \multirow{2}{*}{ Presentase } \\
\hline & $\begin{array}{l}\text { Frekuensi } \\
\text { Stunting }\end{array}$ & $\%$ & $\begin{array}{c}\text { Frekuensi } \\
\text { Non Stunting }\end{array}$ & $\%$ & & \\
\hline $\begin{array}{l}\text { Desa } \\
\text { Sukamulya }\end{array}$ & 2 & $1 \%$ & 184 & $99 \%$ & 186 & $100 \%$ \\
\hline $\begin{array}{l}\text { Desa } \\
\text { Kaliasin }\end{array}$ & 64 & $28.5 \%$ & 161 & $71.5 \%$ & 225 & $100 \%$ \\
\hline Desa Merak & 2 & $1.2 \%$ & 160 & $98.8 \%$ & 162 & $100 \%$ \\
\hline Desa & 7 & $2.1 \%$ & 324 & $97.9 \%$ & 331 & $100 \%$ \\
\hline
\end{tabular}




\begin{tabular}{lcccccc}
\hline Parahu & & & & & & \\
\hline Desa Bunar & 3 & $1.9 \%$ & 150 & $98.1 \%$ & 153 & $100 \%$ \\
\hline $\begin{array}{l}\text { Desa } \\
\text { Buniayu }\end{array}$ & 17 & $14.9 \%$ & 97 & $85.1 \%$ & 114 & $100 \%$ \\
\hline Desa Benda & 5 & $3.6 \%$ & 131 & $96.4 \%$ & 136 & $100 \%$ \\
\hline $\begin{array}{l}\text { Desa } \\
\text { Kubang }\end{array}$ & 23 & $16.8 \%$ & 114 & $83.2 \%$ & 137 & $100 \%$ \\
\hline
\end{tabular}

Berdasarkan tabel 2, dari data hasil kunjungan bayi terdapat temuan Desa yang menyumbang angka stunting tertinggi pada anak usia 0-59 bulan di Wilayah Kerja UPT Puskesmas Sukamulya pada Tahun 2019, adalah Desa Kaliasin sejumlah 64 anak (28.5\%), dan Desa yang paling kecil menyumbang angka stunting pada anak usia 0-59 bulan di Wilayah Kerja UPT Puskesmas Sukamulya pada Tahun 2019, adalah Desa Sukamulya dan Desa Merak berjumlah 2 anak (1\%).

\section{PEMBAHASAN}

Berdasarkan hasil
temuan kunjungan bayi yang
dilakukan oleh tenaga atau
petugas kesehatan Puskesmas
Sukamulya pada tahun 2019,
terdapat temuan 123 kasus
stunting yang terjadi pada anak
usia 0-59 bulan dari 1.444 anak
di delapan desa wilayah kerja

UPT Puskesmas Sukamulya. Temuan kasus stunting ini diurutkan berdasarkan nama desa dari temuan kasus tertinggi hingga temuan kasus terendah, diantaranya Desa Kaliasin 28.5\%, Desa Kubang 16.8\%, Desa Buniayu 14.9\%, Desa Benda 3.6\%, Desa Parahu 2.1\%, Desa Bunar 1.9\% dan Desa Sukamulya dan Desa Merak berjumlah 2 anak (1\%).

$$
\text { Desa Kaliasin }
$$

merupakan desa penyumbang kasus stunting tertinggi pertama pada tahun 2019 di wilayah kerja Puskesmas Sukamulya yaitu dengan jumlah kasus 64 anak dari 123 kasus stunting. Berdasarkan profil data Desa Kaliasin, jumlah penduduk usia 0-15 tahun terdiri dari 3.131 jiwa. Data hasil temuan rekapitulasi kasus stunting di Desa Kaliasin dilihat dari kelompok usia pada anak usia 0-24 bulan ditemukan kasus stunting sejumlah 29 
kasus, dan pada anak usia 25-59

bulan sejumlah 35 kasus.

Berdasarkan hasil pemeriksaan

antropometri, didapatkan nilai

tinggi badan dibawah umur di

Desa Kaliasin terdapat pada

rentan nilai $(-2.00$ s.d -5.52$)$

dimana nilai tersebut berada

dibawah standar median WHO

sehingga termasuk dalam

kategori stunting.

Sasaran bayi dan Balita

di Desa Kaliasin terbagi menjadi tiga kelompok usia diantaranya 0-6 bulan sejumlah 17 orang (laki-laki 9 orang dan perempuan 8 orang), kelompok usia 0-11 bulan 27 orang (lakilaki 14 orang dan perempuan 13 orang), serta kelompok usia 12-59 bulan terdiri dari 97 orang (laki-laki 55 orang dan perempuan 47 orang). Adapun sasaran bayi usia 0-59 bulan di Posyandu Kaliasin sejumlah 126 anak dengan jumlah bayi lakilaki 65 orang dan bayi perempuan 61 orang. Dilihat dari gender atau jenis kelamin, kasus stunting di Desa Kaliasin banyak terjadi pada laki-laki dengan jumlah 38 orang dibandingkan dengan perempuan yaitu 26 orang.
Sedangkan berdasarkan waktu temuan kasusnya, kasus stunting di Desa Kaliasin ditemukan pada bulan Januari sampai dengan Mei, kemudian September.

Berdasarkan penyebab terjadinya stunting salah satunya adalah target pencapaian KIA-KB di Desa Kaliasin pada tahun 2019, didapatkan jumlah anak dengan gizi kurang yaitu13 orang dan 1 orang dengan status gizi buruk. Terdapat 14 orang ibu hamil dengan risiko tinggi Kekurangan Energi Kronik (KEK), dan 5 orang ibu hami dengan risiko tinggi anemia. Dalam pelayanan kebidanan khususnya oleh tenaga bidan desa, puskesmas dan bidan praktek swasta, beberapa ibu hamil dengan resiko tinggi memerlukan pemantauan khusus dalam pelayanan pemeriksaannya, perlu tindak lanjut bila resiko pada kehamilannya tidak dapat ditangani di Desa maka harus dirujuk ke Unit pelayanan yang lebih tinggi yang memadai.

Temuan kasus stunting tertinggi kedua yaitu terdapat di Desa Kubang sejumlah 23 
Jurnal Untuk Masyarakat Sehat (JUKMAS

anak dengan propors

rekapitulasi kasus stunting di

penemuan kasus $16.8 \%$.

Desa Buniayu dilihat dari

Berdasarkan hasil temuan pada

data rekapitulasi stunting di

Puskesmas Sukamulya dengan

pemeriksaan antropometri,

didapatkan nilai tinggi badan

dibawah umur di Desa Kubang

terdapat pada rentan nilai (-

2.24 s.d -4.27) dimana nilai

tersebut berada dibawah

standar median WHO sehingga

termasuk dalam kategori

stunting. Dilihat dari gender

atau jenis kelamin, kasus

stunting di Desa Kubang lebih

banyak terjadi pada perempuan

dengan jumlah 12 orang

dibandingkan dengan laki-laki

yaitu 11 orang. Sedangkan

berdasarkan waktu temuan

kasusnya, kasus stunting di

Desa Kubang ditemukan pada

bulan Agustus hingga bulan

November 2019.

Temuan kasus stunting

tertinggi ketiga yaitu terdapat

di Desa Buniayu sejumlah 17

anak dengan proporsi

penemuan kasus $14.9 \%$.

Berdasarkan profil data Desa

Buniayu, jumlah penduduk usia

0-15 tahun terdiri dari 1.483

jiwa. Data hasil temuan

kelompok usia pada anak usia

0-24 bulan ditemukan kasus

stunting sejumlah 8 kasus, dan

pada anak usia 25-59 bulan

sejumlah 9 kasus. Berdasarkan

hasil pemeriksaan

antropometri, didapatkan nilai

tinggi badan dibawah umur di

Desa Buniayu terdapat pada

rentan nilai (-2.02 s.d -4.42$)$

dimana nilai tersebut berada

dibawah standar median WHO

sehingga termasuk dalam

kategori stunting.

Sasaran bayi dan Balita

di Desa Buniayu terbagi

menjadi tiga kelompok usia diantaranya 0-6 bulan sejumlah 7 orang (laki-laki 4 orang dan perempuan 3 orang), kelompok usia 0-11 bulan 15 orang (lakilaki 7 orang dan perempuan 8 orang), serta kelompok usia 12 59 bulan terdiri dari 48 orang (laki-laki 24 orang dan perempuan 24 orang). Adapun sasaran bayi usia 0-59 bulan di Posyandu Buniayu sejumlah 54 anak dengan jumlah bayi lakilaki 28 orang dan bayi perempuan 26 orang. Dilihat dari gender atau jenis kelamin, 
kasus stunting di Desa Buniayu banyak terjadi pada perempuan sejumlah $\quad 10 \quad$ orang dibandingkan dengan laki-laki sejumlah 7 orang. Sedangkan berdasarkan waktu temuan kasusnya, kasus stunting di Desa Buniayu ditemukan pada bulan Januari, Februari, Juni, dan Desember. 2019. Berdasarkan penyebab terjadinya stunting salah satunya adalah target pencapaian KIA-KB di Desa Buniayu, didapatkan jumlah anak dengan gizi kurang yaitu 1 orang dan 1 orang dengan status gizi buruk.

Berdasarkan hasil evaluasi temuan kasus stunting diatas, penting sekali untuk tenaga kesehatan serta lintas sektor dan stakeholders untuk saling bekerjasama dalam upaya pencegahan dan penanganan kasus stunting. Hal ini berkaitan dimana stunting memiliki dampak yang besar terhadap tumbuh kembang anak dan juga perekonomian Indonesia di masa yang akan datang. Dampak stunting terhadap kesehatan dan tumbuh kembang anak sangat merugikan. Stunting dapat mengakibatkan gangguan tumbuh kembang anak terutama pada anak berusia di bawah dua tahun.

$$
\text { Anak-anak yang }
$$

mengalami stunting pada umumnya akan mengalami hambatan dalam perkembangan kognitif dan motoriknya yang akan mempengaruhi produktivitasnya saat dewasa. Selain itu, anak stunting juga memiliki risiko yang lebih besar untuk menderita penyakit tidak menular seperti diabetes, obesitas, dan penyakit jantung pada saat dewasa. Kondisi kesehatan dan gizi ibu sebelum dan saat kehamilan serta setelah persalinan mempengaruhi pertumbuhan janin dan risiko terjadinya stunting. Faktor lainnya pada ibu yang mempengaruhi adalah postur tubuh ibu (pendek), jarak kehamilan yang terlalu dekat, ibu yang masih remaja, serta asupan nutrisi yang kurang pada saat kehamilan.

Kemudian, permasalahan kekurangan gizi pada anak erat kaitannya 


dengan tingkat pendapatan
keluarga. Keluarga dengan
tingkat pendapatan yang
rendah erat kaitannya dengan
kemampuan dalam memenuhi
asupan yang bergizi dan
pelayanan kesehatan untuk ibu
hamil dan balita. Pada
umumnya pendapatan yang
rendah memiliki masalah dalam
hal akses terhadap bahan
makanan terkait dengan daya
beli yang rendah. Selain
pendapatan, kerawanan
pangan di tingkat rumah tangga juga sangat dipengaruhi oleh inflasi harga pangan. Sedangkan sanitasi dan keamanan pangan dapat meningkatkan risiko terjadinya penyakit infeksi ${ }^{(8)}$.

Faktor penting lain yang mempengaruhi terjadinya masalah kekurangan gizi pada anak balita adalah buruknya pola asuh terutama pemberian ASI eksklusif akibat rendahnya tingkat pengetahuan orang tua, buruknya kondisi lingkungan seperti akses sanitasi dan air bersih, rendahnya akses pada pelayanan kesehatan. Penyakit infeksi yang disebabkan oleh higiene dan sanitasi yang buruk (misalnya diare dan kecacingan) dapat menganggu penyerapan
nutrisi pada proses pencernaan.
Beberapa penyakit infeksi yang
diderita bayi dapat menyebabkan berat badan bayi turun. Jika kondisi ini terjadi dalam waktu yang cukup lama dan tidak disertai dengan pemberian asupan yang cukup untuk proses penyembuhan maka dapat mengakibatkan stunting. Melihat faktor penyebab permasalahan stunting yang multi dimensi, penanganan masalah gizi harus dilakukan dengan pendekatan multi sektor yang terintegrasi ${ }^{(9)}$ Tantangan utama dalam pelaksanaan intervensi pencegahan stunting terintegrasi adalah membangun komitmen dan dukungan yang bekelanjutan dari pimpinan tertinggi dalam memprioritaskan pembangunan gizi di Indonesia. Tantangan selanjutnya adalah memastikan intervensi pencegahan stunting dapat dilaksanakan secara terintegrasi dan konvergen dengan pendekatan multisektor sampai ke tingkat daerah. Oleh karena itu, advokasi dan koordinasi 


\begin{abstract}
harus terus dilakukan baik di tingkat pusat maupun daerah untuk meningkatkan komitmen dan menyamakan persepsi terhadap tujuan pelaksanaan kegiatan percepatan pencegahan stunting. Upaya pencegahan stunting juga harus dilaksanakan dengan menggunakan pendekatan berbasis hasil, pemberdayaan masyarakat, dan perubahan perilaku.
\end{abstract}

Upaya pencegahan dan penanganan lainnya yang dapat dilakukan untuk kasus stunting meliputi pemberian vitamin $A$ yang bertujuan untuk mencegah terjadinya KVA (Kekurangan Vitamin A), kemudian distribusi zat besi yaitu tabet besi (Fe) yang diberikan pada ibu hamil sebanyak 90 tablet selama kehamilannya. Fe-1 adalah Fe yang pertama diberikan pada kunjungan pertama pada kehamilannya sedangkan Fe-3 adalah pemberian Fe yang ke tiga kalinya pada kunjungan pemeriksaan berikutnya dengan jumlah tablet $\mathrm{Fe} 90$ tablet yang sudah diberikan. Kemudian pemantauan Status

\begin{abstract}
Gizi dan Bulan Penimbangan yang dilakukan dengan tujuan yang sama yaitu untuk melihat status gizi Balita diwilayah kerja, PSG dilakukan setahun sekali dengan jumlah Balita 100 setiap Desanya, sedangkan BPB dilakukan diseluruh Posyandu dengan sasaran semua Balita, dan Pemberian Makanan Tambahan (PMT) untuk bayi dan balita dengan status gizi kurang dan gizi buruk yang tepat sasaran. Selanjutnya melaksanakan Pelayanan
\end{abstract} Imunisasi rutin untuk bayi dan ibu hamil yang dilaksanakan di posyandu, Puskesmas dan pelayanan Klinik Bidan swasta dengan kunjungan waktu yang telah terjadwal setiap bulannnya. ${ }^{(10)}$

Berdasarkan hasil evaluasi temuan kasus stunting tersebut, penting sekali untuk tenaga kesehatan serta lintas sektor dan stakeholders untuk saling bekerjasama dalam upaya pencegahan dan penanganan kasus stunting. Hal ini berkaitan dimana stunting memiliki dampak yang besar terhadap tumbuh kembang anak dan juga perekonomian Indonesia di masa 
yang akan datang. Terutama di Desa Kaliasin yang merupakan penyumbang angka stunting tertinggi, tentunya hal ini harus menjadi perhatian khusus bagi UPT Puskesmas Sukamulya dalam upaya menurunkan angka kejadian stunting diwilayah kerjanya.

\section{SIMPULAN}

Data hasil temuan kunjungan bayi di Desa yang menyumbang angka stunting tertinggi pada anak usia 0-59 bulan di Wilayah Kerja UPT Puskesmas Sukamulya pada Tahun 2019, adalah Desa Kaliasin 28.5\%, Desa Kubang 16.8\%, Desa Buniayu 14.9\%, Desa Benda 3.6\%, Desa Parahu 2.1\%, Desa Bunar 1.9\% dan Desa Sukamulya dan Desa Merak berjumlah 2 anak (1\%).

Angka kejadian stunting di wilayah kerja UPT Puskesmas Sukamulya disebabkan karena terdapatnya kondisi ibu hamil dengan kekurangan energi kronik (KEK), ibu hamil dengan anemia, bayi lahir dengan BBLR, kondisi bayi sama seperti ibu nya sehingga penurunan sifat secara genetik, pola asuh yang salah dan kurang baik, tingkat pendidikan ibu yang rendah sehingga terbatasnya pengetahuan ibu yang dimiliki, pola makan asupan nutrisi yang tidak seimbang seperti halnya konsumsi makanan dengan rendah protein, dan faktor ekonomi atau tingkat pendapatan keluarga yang masih rendah.

\section{DAFTAR PUSTAKA}

1. BAPPENAS dan UNICEF. United Nations Children's Fund, World Health Organization, World Bank Group. 2018. Levels and Trends in Child Malnutrition: Key Findings of The 2018 Edition of The Joint Child Malnutrition Estimates.

2. Buletin Data dan Informasi Kesehatan, situasi balita pendek (stunting) di Indonesia, tahun 2018

3. Dinas Kesehatan Kabupaten Tangerang, Surveilans Gizi tahun

2019 https://tirto.id/djKM diunduh pada hari Jum'at 7 Februari tahun 2020 pukul 01.00 WIB. 
Jurnal Untuk Masyarakat Sehat (JUKMAS

4. Profil UPT Puskesmas

Sukamulya

,Profil

Kesehatan UPT Puskesmas

Sukamulya Tahun 2019.

5. Riset Kesehatan Dasar (Riskesdas) tentang stunting tahun 2013

6. Riset Kesehatan Dasar (Riskesdas) tentang stunting tahun 2018

7. Notoatmodjo S, Metodologi Penulisan Kesehatan, Rineka Cipta tahun 2018

8. Kementrian Kesehatan Republik Indonesia, Kebijakan Dan Strategi Penanggulangan Stunting

Di Indonesia, tahun 2019
9. Kementerian Perencanaan Pembangunan Nasional (Bappenas) dan United Nations Children's Fund. 2017. Laporan Baseline SDG tentang Anak-Anak di Indonesia. Jakarta:

10. Keputusan Menteri Kesehatan Republik Indonesia tentang standar antropometri penilaian status gizi anak tahun 2010. 